\title{
THE DYNAMICS OF EXTREME POVERTY IN DEVELOPING COUNTRIES
}

\author{
Edmore Mahembe \\ Department of Economics, University of South Africa, South Africa \\ E-mail: emahembe@gmail.com \\ Professor Nicholas M. Odhiambo \\ Department of Economics, University of South Africa, South Africa \\ E-mail: nmbaya99@yahoo.com
}

(Received: April 2018; Accepted: June 2018)

\begin{abstract}
This paper aims to analyses the trends and dynamics of extreme poverty in developing countries. The study attempts to answer one critical question: has the world achieved its number one Millennium Development Goal (MDG) target of reducing extreme poverty by half by 2015 ? The methodology used in this study mainly involves a descriptive data analysis during the period 1981-2015. The study used the World Bank's US\$1.90 a day line (popularly known as $\$ 1$ a day line) in 2011 prices to measure the level of absolute poverty. In order to analyze the dynamics of poverty across different regions, the study grouped countries into five regions: i) sub-Saharan Africa; ii) East Asia and the Pacific; iii) South Asia; iv) Europe and Central Asia; and v) Latin America and the Caribbean. The study found that in 1990, there were around 1.9 billion people living below US $\$ 1.90$ a day (constituting 36.9 percent of the world population) and this number is estimated to have reduced to around 700 million people in 2015, with an estimated global poverty rate of 9.6 percent. The world met the MDG target in 2010, which is five years ahead of schedule. However, extreme poverty is becoming increasingly concentrated in sub-Saharan Africa (SSA) and South Asia (SA), where its depth and breadth remain a challenge. SSA remains the poorest region, with more than 35 percent of its citizens living on less than US\$1.90 a day. Half of the world's extremely poor people now live in SSA, and it is the only region which has not met its MDG target.
\end{abstract}

Key words: Extreme poverty; poverty measurement; millennium development goals (MDGs); developing countries

\section{JEL CLASSIFICATION: I32}

\section{Introduction}

Historically, the phrases 'economic development' and 'development economics' were thought of as synonymous with economic growth. In recent years, however, these terms have come to be thought of as 'poverty reduction' (Deaton, 2006). The World Bank (1990, p. 24) asserts that "reducing poverty is the fundamental objective of economic development". Clunies-Ross, et al. (2009, p. 595) argue that 
the promulgation of the Millennium Development Goals (MDGs) led to the shifting of emphasis on foreign aid motive from increasing economic growth rates to poverty reduction. But how has the developing world fared in their fight against poverty? Has the world achieved its number one MDG target of reducing extreme poverty by half by 2015 from the 1990 level? This paper is aimed at answering these two broad questions.

According to Ravallion (2016, p. 2) in 1820 around 80percent of the world's population lived in material conditions which are similar to those of the poorest 20percent today. This suggests that the world has made progress in reducing poverty over the years. However, this progress has been uneven over time and space (Ravallion, 2016, p. 2), with poverty now concentrated in developing countries. Developing countries are typically classified into six geographical regions, namely: East Asia and Pacific (EAP), Eastern Europe and Central Asia (ECA), Latin America and the Caribbean (LAC), Middle East and North Africa (MENA), South Asia (SA) and Sub-Saharan Africa (SSA). According to Atkinson and Bourguignon (2014), developing countries cover almost 75 percent of the total world land area and constitute around 85 percent of the total world population. The latest World Bank (2017c) and United Nations (UN) figures for 2015 show that the total population in developing countries has almost doubled over the last 35 years to around 13.5 billion and that the poorest region in terms of gross national income (GNI) per capita (Atlas method) is SA followed by SSA.

The paper starts by a brief literature review in Section 2 and proceeds to illustrate the measures of poverty used in this study in the methodology section. Section 4 presents the main findings, which include a broad overview of global poverty, the discussion on the regional dynamics of poverty and an exploration on the question of whether the world has met the MDGs. Section 6 concludes the study with suggestions on further directions of research.

\section{An Overview of Regional and Global Poverty Trends}

One of the main challenges in the understanding and fight against global poverty is obtaining reliable measures of poverty which are comparable across countries (Besley \& Burgess, 2003; World Bank, 2015). This section attempts to give a broad overview of the global and regional trends in different dimensions of poverty such as income (consumption), education, and health.

Table 1 gives a summary of the wellbeing of citizens by region in terms of gross domestic product (GDP) per capita, life expectancy, mortality rates and school enrolment. The GDP per capita gives a measure of average annual income per person, assuming that the income in the region is distributed equally. As shown in Table 1, the average income per person increased over the years but there are large 
regional disparities. On average, the world has recorded an increase in GDP per capita of 178 percent from 1960 to 2015. Over the same period, EAP recorded the highest growth of 1814 percent; from US\$287 to US\$5 500. This is followed by SA with a growth of 409 percent, with the least growth being recorded in the SSA region which witnessed a mere 54 percent (from US\$1 074 to US\$1 659) in over more than half a century. It is also important to note that by 1960 SSA was almost 4 times richer than EAP but now there is a complete reversal as EAP is now about 3 times richer.

Table 1. Monetary and Non-Monetary Poverty Indicators by Region of the World

\begin{tabular}{|c|c|c|c|c|c|c|c|c|c|c|c|c|}
\hline \multirow[t]{2}{*}{ Region } & \multicolumn{3}{|c|}{$\begin{array}{l}\text { GDP per capita (constant } \\
2010 \text { US\$) }\end{array}$} & \multicolumn{3}{|c|}{$\begin{array}{c}\text { Life expectancy at birth, } \\
\text { total (years) }\end{array}$} & \multicolumn{3}{|c|}{$\begin{array}{c}\text { Mortality rate, infant (per } \\
1,000 \text { live births) }\end{array}$} & \multicolumn{3}{|c|}{$\begin{array}{l}\text { School enrollment, } \\
\text { secondary (\% gross) }\end{array}$} \\
\hline & 1960 & 1990 & 2015 & 1960 & 1990 & 2015 & 1960 & 1990 & 2015 & 1970 & 1990 & 2014 \\
\hline World & 3,690 & 7,154 & 10,242 & 52 & 65 & 72 & 122 & 63 & 32 & 41 & 51 & 75 \\
\hline High income & 11,750 & 29,283 & 41,459 & 68 & 75 & 81 & 36 & 10 & 5 & 78 & 92 & 106 \\
\hline Lower middle income & 556 & 947 & 2,018 & 47 & 63 & 70 & 161 & 83 & 40 & & & \\
\hline \multicolumn{13}{|l|}{\begin{tabular}{|l|}
$\begin{array}{l}\text { Developing Countries } \\
\text { (excluding high income) }\end{array}$ \\
\end{tabular}} \\
\hline Europe \& Central Asia & & 6,261 & 8,333 & 63 & 68 & 72 & & 39 & 15 & 81 & 91 & 106 \\
\hline Middle East \& North Africa & & 2,724 & & 47 & 65 & 72 & 168 & 52 & 21 & 26 & 57 & 79 \\
\hline East Asia \& Pacific & 287 & 945 & 5,500 & 45 & 68 & 74 & & 45 & 15 & 35 & 44 & 88 \\
\hline Latin America \& Caribbean & 3,552 & 6,275 & 9,027 & 56 & 68 & 75 & 121 & 44 & 15 & 27 & 76 & 94 \\
\hline South Asia & 314 & 553 & 1,599 & 42 & 58 & 68 & 168 & 92 & 42 & 23 & 36 & 65 \\
\hline Sub-Saharan Africa & 1,074 & 1,252 & 1,659 & 40 & 50 & 59 & & 108 & 56 & 13 & 23 & 43 \\
\hline
\end{tabular}

Source: World Bank (2017 c)

Though GDP per capita offers useful and thought-provoking insight on prosperity levels (Schaffner, 2014, p. 2), it doesn't give an accurate picture of the level of deprivation and standard of living. It has to be complemented by other non-income measures of poverty. Table 1 also shows that for many people in developing countries, life is short, the probability of a child dying is still very high and school enrolments are still awfully low. On average, SSA is ranking lowest in all measures. The life expectancy in SSA is only 59 years compared to 81 years for high-income countries. One out of every seventeen babies born in SSA dies before the age of 5 years while only 43percent of children attend secondary school. The main focus of this paper, however, is monetary measures of poverty whose trends are discussed in greater detail in the main findings section.

\section{Research methodology}

Literature is replete with various definitions of poverty (see for example Bundy, 2016, and Todaro and Smith, 2012). The World Bank (1990, p. 26) defines poverty as the inability to attain a minimal standard of living. Todaro and Smith $(2012$, p. 2) qualify poverty, and define extreme or absolute poverty as "a situation of being

20 DE GRUYTER OPEN
Studia Universitatis "Vasile Goldis" Arad. Economics Series Vol 28 Issue 2/2018 ISSN: 1584-2339; (online) ISSN: 2285 - 3065

Web: publicatii.uvvg.ro/index.php/studiaeconomia. Pages $18-35$ 
unable to meet the minimum levels of income, food, clothing, healthcare, shelter, and other essentials". For its analysis, this paper uses the assets-based income or monetary indicators of poverty, which are widely used by the United Nations, World Bank and other development institutions for global poverty measurements and determination of foreign aid allocation (Deaton, 2010, p. 6).

We use the World Bank's US\$1.90 a day line (popularly known as $\$ 1$ a day line[1]) in 2011 prices (World Bank, 2017a), which measures absolute poverty. Following the work of Foster et al. (1984), this class of poverty measures could be decomposed into three poverty measures, namely poverty-headcount index[2], the poverty-gap (PG) index[3], and the squared poverty-gap (SPG) index[4] (Schaffner, 2014). The main advantage of this class of poverty measures is that they are easily comparable across countries and geographical regions. Using descriptive data analysis for the period 1981 to 2015, the study aims to answer one critical question: has the world achieved its number one MDG target of reducing extreme poverty by half by 2015 ?

\section{Main Findings}

\subsection{Global extreme poverty levels}

Global poverty levels have fallen sharply over the last three decades. As shown in Figure 1, the World Bank (2016) estimates that more than 1 billion people have been lifted out of extreme poverty during the last three and half decades (1981 to 2015). However, there were still around one-tenth of the global population that lived on less than US\$1.90 a day, which was around 700 million people in 2015 (World Bank, 2016, p. xv).

Figure 2 plots the US $\$ 1.90$ a day poverty rate for the 6 regions and the total for all developing countries. As shown in the graph, the total poverty rate for all developing countries decreased from around 54.7 percent in 1981 to 13 percent in 2013 and is estimated to have decreased further to 11.9 percent in 2015. Figure 2 also shows that there are still huge regional disparities on the levels of progress in the fight against global poverty. This was also observed by Ravallion (2011, p. 79) who remarked that progress against poverty has been uneven over time and space. A comparison of progress in poverty reduction between the six regions over this period also shows that there has been a striking re-ranking. The marked reversal in fortunes happened within the first two decades (the 1980s and 1990s). For example, the regions with the highest poverty rate in 1981 were EAP at 80.5 percent, SA at 54.5 percent and SSA at 49.2 percent. The EAP region had the greatest number of people in extreme poverty during the 1980s and the early 1990s. However, by the early 1990s, EAP swapped places with SSA. From then on, SSA remained the poorest region, though poverty rates have been decreasing from 
Mahembe, E., Odhiambo. N. M. (2018)

The dynamics of extreme poverty in developing countries

around 2000. In contrast, EAP recorded the sharpest decrease in poverty rates during the entire study period, from 80.5 percent in 1981 to less than 10 percent in 2011 and is projected to be less than 5 percent in 2015 .

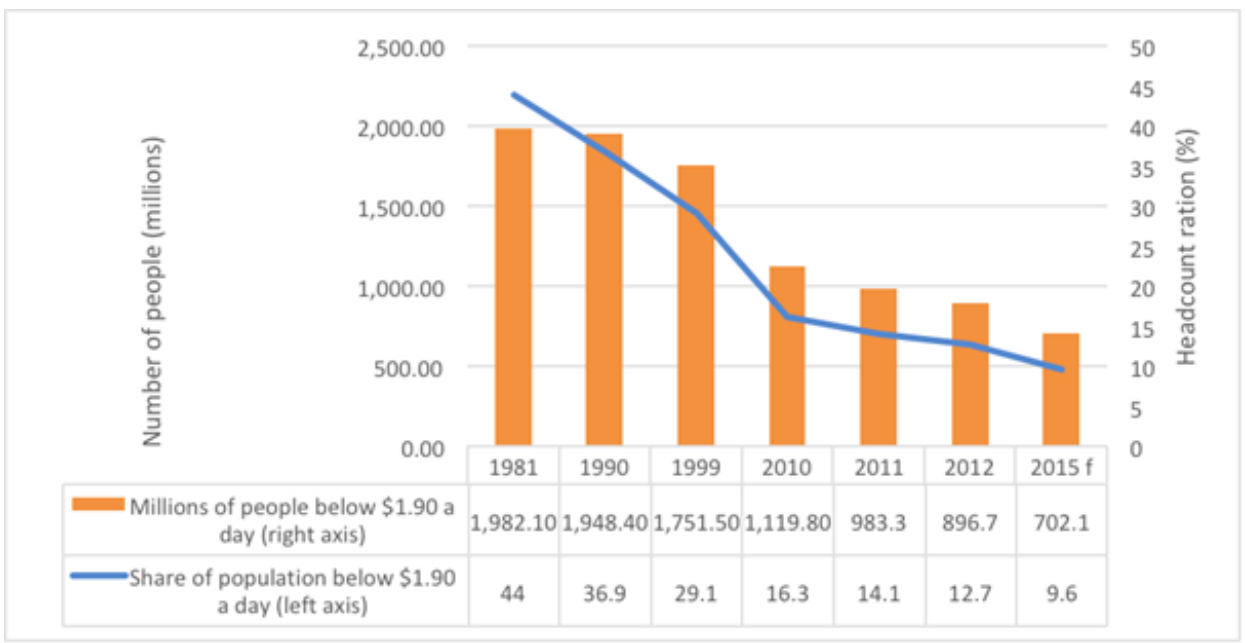

Figure 1. Global Poverty Levels

Source: World Bank (2016)

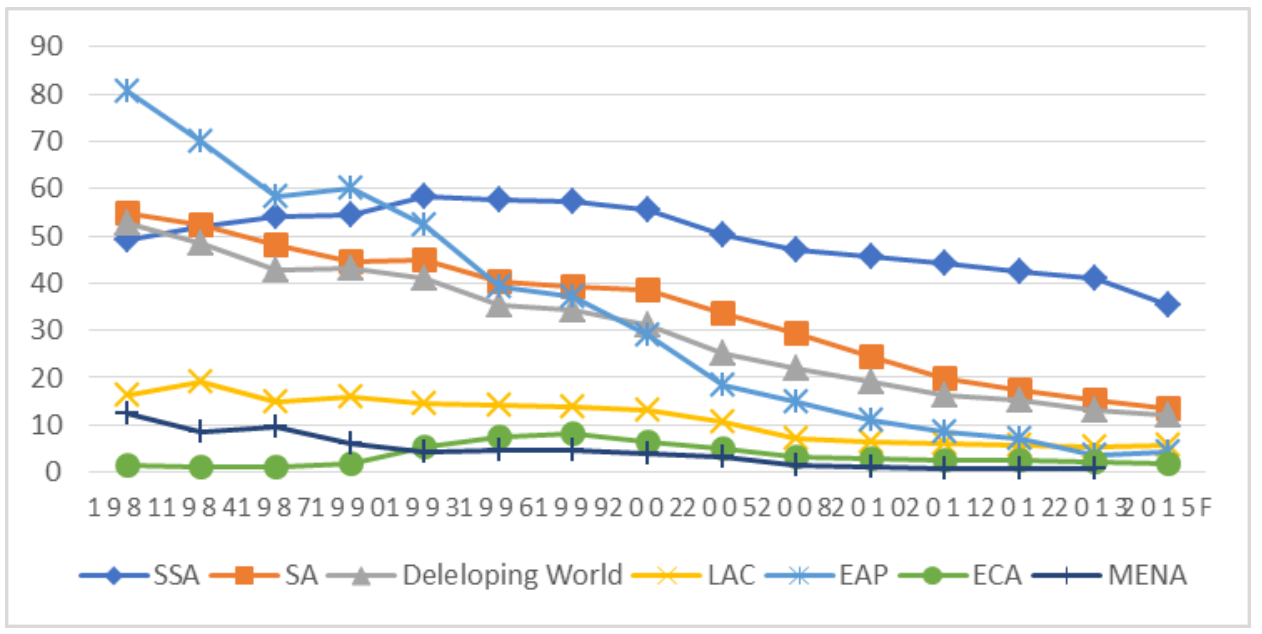

Figure 2. Regional Dynamics of Poverty ( $\$ 1.90$ a day)

Source: World Bank (2016 and 2017 a) 
Both Figure 1 and Figure 2 also show that the decrease in incidences of poverty was greater in some periods compared to others. Global poverty rates fell by large margins between 1981 and around 2010, and the most rapid decline occurred during the 2000s. More than one billion people escaped from extreme poverty during this period. The estimated figures for 2015 show that global poverty is now concentrated in three regions; SSA, SA and LAC. However, the other two regions have reached a US $\$ 1.9$ per day headcount poverty rate of less than 15 percent except SSA's which remained stubbornly high at 35.2 percent in 2015 . This means that there is still around 350 million people who are living on less than US\$1.9 per day, and this figure is around half of the world's poor. It is not a surprise that the top ten poorest countries in the world are in SSA [5].

Figure 3 shows the distribution of the estimated 700 million people living below US $\$ 1.90$ a day poverty line in 2015. SSA and SA regions accounted for more than 80 percent of the global poor in 2015. SSA, with around 350 people living on less than a US\$1.90 per day, had about half of the world's poverty-stricken population.

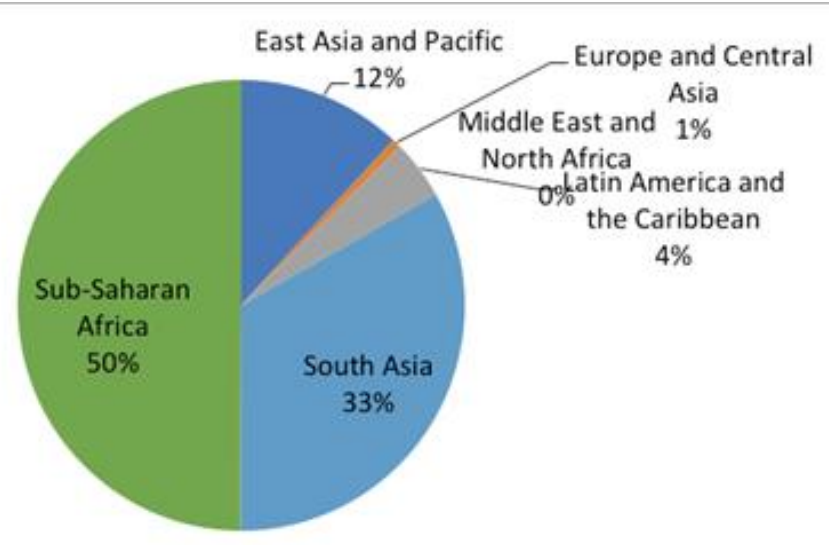

Figure 3. Regional Distribution of People Living below U\$1.90-a-day Poverty Line (2013 PPP), 2015

Source: World Bank (2016)

Figure 4 and Figure 5 illustrate the top improved countries and the least performing countries in terms of poverty reduction, respectively. Bhutan, China, Nepal, Vietnam and Timor-Leste, in decreasing order, recorded the highest poverty rate reduction of above 70 percentage points between the period 1981 and 2013. Bhutan managed to reduce headcount poverty rate from a high of 97 percent to 1 percent 
between the same period. China's remarkable progress is regarded as a world miracle. The country lifted almost 200 million people out of extreme poverty during this period; recording a reduction in the poverty rate from 88 percent to less than 2 percent. More than 60 percent of the countries in Figure 4 are in EAP and SA regions and only 2 countries are from SSA (Madagascar and Liberia).

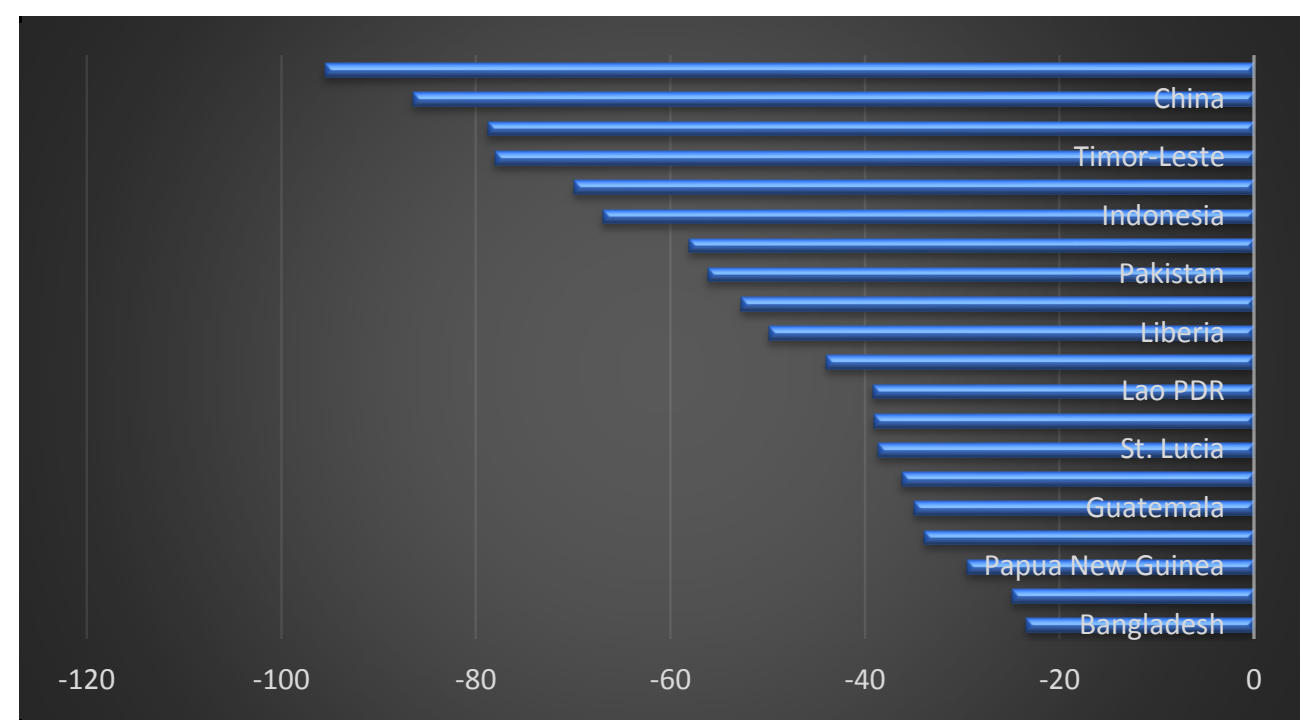

Figure 4. Top 20 Most Improved Countries (1981-2013)

Source: World Bank (2017 a)

A total of fifty-three (53) developing countries across the world recorded an increase in the poverty rate between the period 1981 and 2013. Eighty percent of the 20 worst performing countries are in SSA (Figure 5). Cabo Verde saw the poverty rate increased by almost 60 percentage points over the same period, followed by Guinea (57 percent) and Uganda ( 52 percent). This shows that the fortunes of the majority of Africans have been getting worse, not better.

Furthermore, an analysis of the levels poverty rate by the population of people living on less than US\$1.90 a day, reveals that about three-fifths of the world's extreme poor are concentrated in only five countries, namely Bangladesh, China, the Democratic Republic of Congo, India, and Nigeria. Moreover, the top ten poor countries in terms of population in extreme poverty consist of slightly over 70 percent of world's extreme poor. Other countries in the top ten include Ethiopia, Indonesia, Madagascar, Pakistan, and Tanzania. 


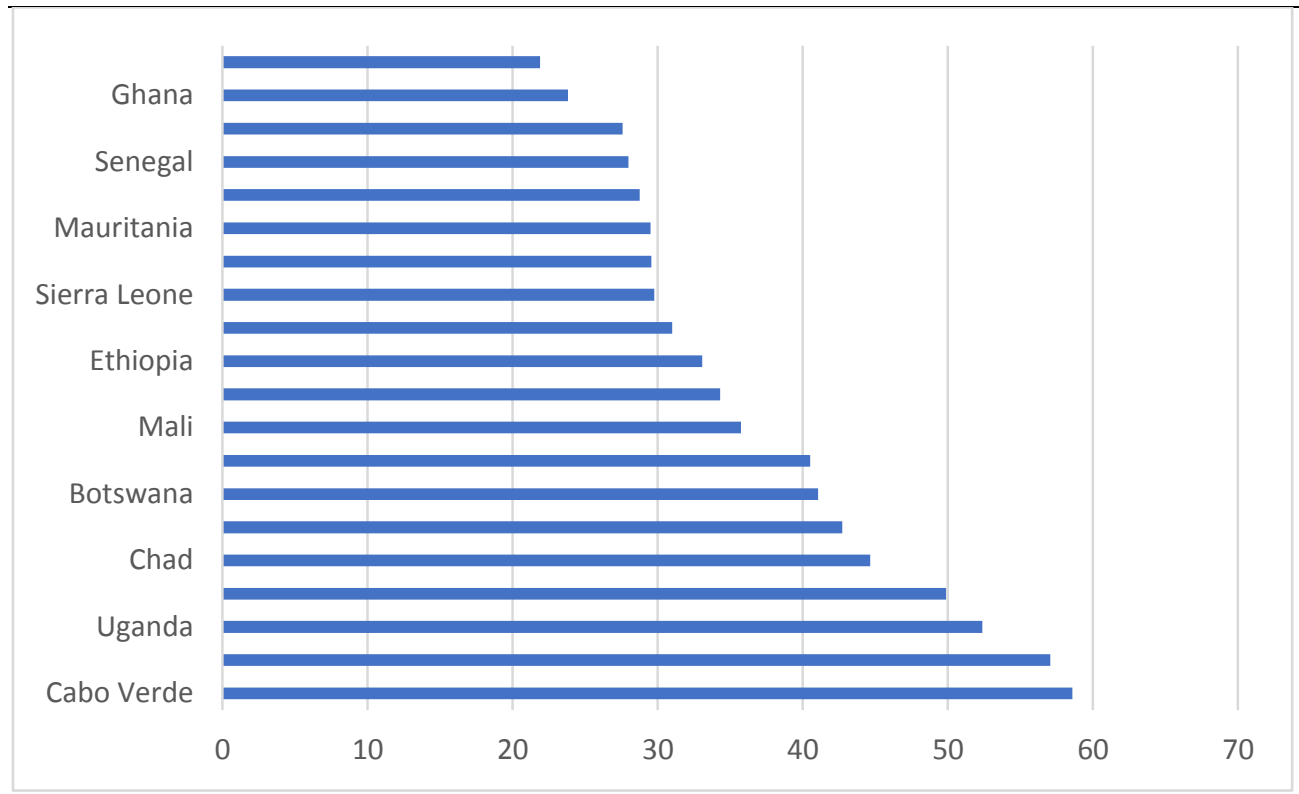

Figure 5. 20 Worst Performing Countries (1981-2013): Increase in Poverty Rates Source: World Bank (2017 a)

\subsection{Regional Dynamics of Poverty \\ 4.2.1. Sub-Saharan Africa}

Until recently, data on poverty levels in SSA was scant. Early estimates of poverty for SSA were done by Ravallion, et al. (1991), Chen, et al. (1994), Ravallion and Chen (1997) and Ali and Thorbecke (2000, p. 9). Ravallion, et al. (1991) developed an "absolute poverty line", around US\$1 per day, and then used it to estimate the number of people living in absolute poverty in 1985. According to this poverty measure, the percentage of people living in absolute poverty in SSA was estimated at 46.9 percent. Chen, et al. (1994) used a sample of 14 SSA countries (representing around 37 percent of the total population) to estimate the level of poverty between 1985 and 1990 . The poverty measurement used was a 'poverty incidence curve (PlC)'[6], and results showed that poverty increased during this period. Ravallion and Chen (1997) used an international poverty line of US\$1 per person per day in 1985 PPP to estimate the level of poverty in SSA[7], and found that poverty increased between 1987 and 1993 for the two poverty measures (i) head count ratio, which increased from 38.5 percent in 1987 to 39.1 percent in 1993 and (ii) poverty gap index which increased by one percentage point from 14.4 percent to 15.3 percent over the same period. 
Figure 6 shows the poverty levels in SSA in comparison to world poverty trends, based on recent data from the World Bank. In 1990, SSA had 288 million people who were living below US $\$ 1.90$ a day and this number has increased to 347 million by 2015. In percentage terms, SSA used to have 15 percent of the world's extremely poor people (living below US $\$ 1.90$ a day) and this has increased to almost 50 percent between the period 1990 to 2015[8]. This shows that while other regions have been lifting out remarkable numbers of people from extreme poverty, more families in SSA are being entrapped in poverty.

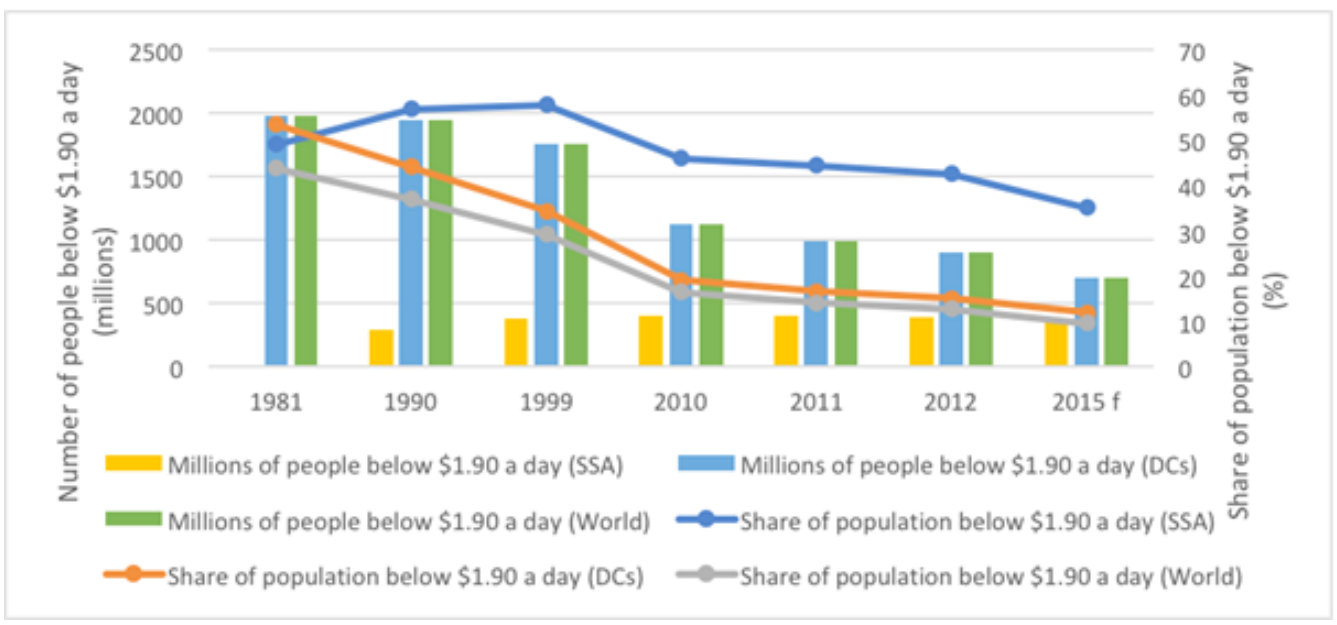

Figure 6. Sub-Saharan Africa poverty levels compared to world trends Source: World Bank (2016 and 2017 a)

Figure 6 also shows that the headcount index ratio for SSA was 49.1 percent in 1981 and it peaked at 58 percent in 1999 before starting on a gradual decrease over the years to an estimated 35.2 percent in 2015 . This 35.2 percent is still extremely high compared to the developing country average of 11.9 percent and the world average of 9.6 percent. The developing country headcount index ratio was 53.5 percent in 1981, which is over 4 percentage points higher than the SSA ratio. The overall analysis of poverty in SSA has shown that PG index (poverty depth) and SPG index (poverty-severity index) followed the same trend with the headcount index[9].

Overally, the analysis of poverty trends in SSA against global trends has revealed that of the 700 million people in 2015 who lived in extreme poverty, the majority were in the SSA region. This shows that SSA is home to most of the deeply poor and poverty depth and breadth remain a dominant challenge in the region. Though 
some specific countries in the region have recorded impressive decrease in poverty levels, 16 countries out of 45 showed evidence of an increase in the proportion of the number of people living below US $\$ 1.90$ a day. Thus, the number of people living in extreme poverty is increasing in these countries.

According to the World Bank (1990, p. 5), the increase in poverty in SSA during the 1980s and 1990s was mainly because of slow economic growth coupled with rapid population growth. Perkins, et al. (2013) argue that much of the progress in the fight against global poverty, which saw the reduction of the world's headcount index ratio from 44 percent in 1991 to less than 10 percent in 2015, was strong growth which was recorded in many regions of the world. They conclude that "economic growth tends to be good for the poor" (Perkins, et al., 2013, p. 193). For the majority of the countries in SSA, the 1980s to 1990s period is characterized by a change of governance from colonial to independent government regimes (Mahembe, 2014 and Tita \& Aziakpono, 2016). Most countries adopted the economic structural adjustment programmes (ESAPs) which emphasized the liberalization and opening of the financial sectors as opposed to government control as practised by previous regimes (Tita \& Aziakpono, 2016, p. 9). The growing global share of poor people in SSA is also a reflection of slower poverty reduction amid rapid population growth (World Bank Group, 2016, pp. 5-6).

\subsubsection{East Asia and the Pacific}

The East Asia and Pacific (EAP)[10] region have recorded the most dramatic fall in the proportion of people living in extreme poverty in recent history. As shown in Figure 7, EAP had 80.6 percent of its people (around 1.1 billion) living at less than US $\$ 1.90$ a day in 1981 and by 2010 nearly one billion people had been lifted from extreme poverty. The EAP registered a dramatic decline, which has been described as miraculous (Quibria, 2002). The region transformed itself from being the poorest, with around 58 percent of the world's poorest people in 1981, by lifting up more than a billion people out of extreme poverty in three and half decades. By 2015 only around 12 percent of the world's poorest were from EAP. The World Bank (2016, p. 4) estimate that about 65 million people were lifted out of extreme poverty in EAP between 2012 and 2015.

The headcount, poverty gap and squared poverty-gap indices for EAP have been decreasing dramatically over the years. The poverty headcount index fell from 80.46 percent in 1981 to 3.54 percent by 2013 and the poverty gap fell from 38.23 percent to 0.66 percent over the same period. The SPG, which measures the severity of poverty, decreased from 21.59 to 0.22 . According to the World Bank and International Monetary Fund (2015), the MDGs could have played a part in the 
fight against poverty in EAP. Their report, titled "Global Monitoring Report 2015/2016: Development Goals in an Era of Demographic Change" argue that the MDGs were effective in EAP in influencing local priorities, shaping national budgets, and protecting social expenditures. However, it's important to note that even before the promulgation of the MDGs in 2000, the number of poor people in EAP was already falling. The EAP region reached its MDG 25-year target of 'halving the proportion of population below US\$1 per day between 1990 and 2015' in 13 years' time. The region recorded a fall in headcount index from 60.23 percent in 1990 to 28.95 percent in 2002, which is a decrease of more than half.

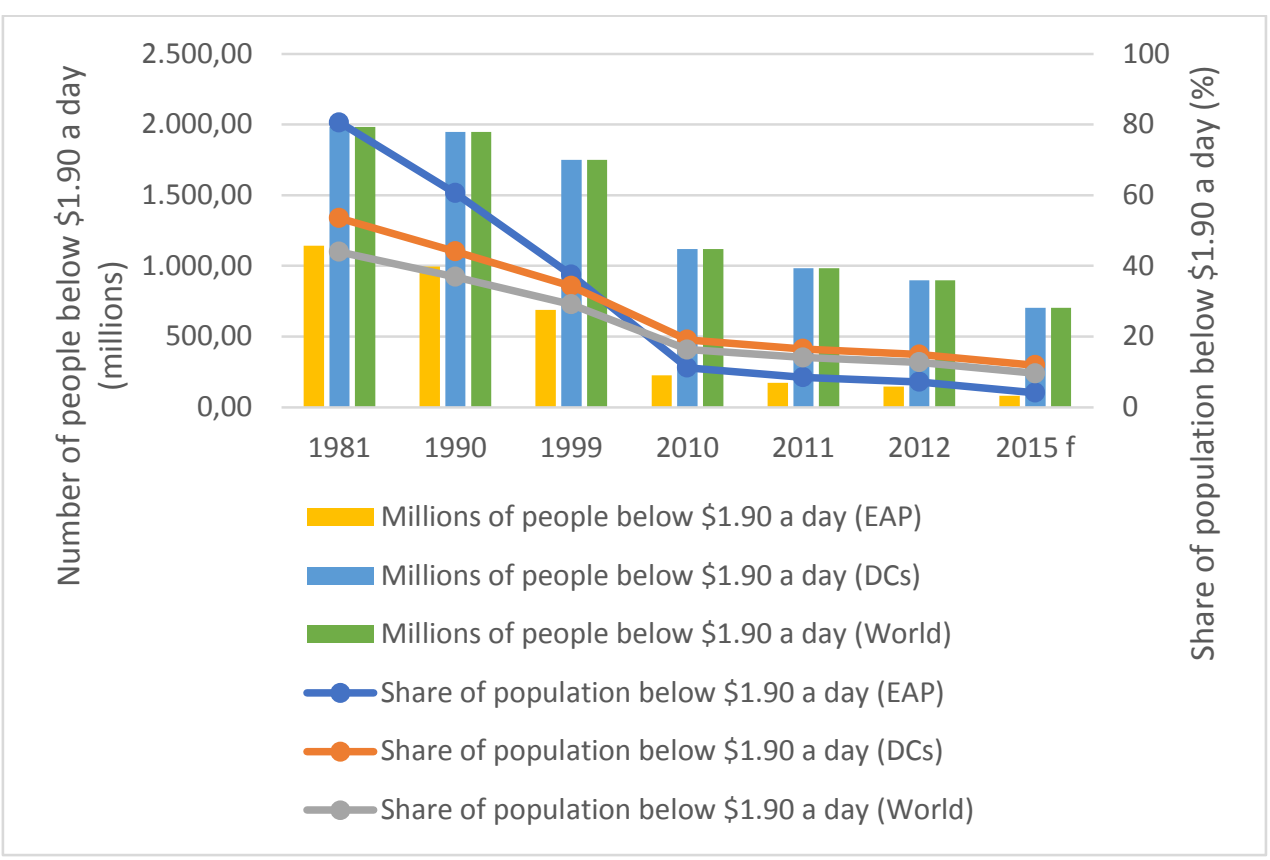

Figure 7. East Asian and Pacific poverty levels compared to world trends $(\$ 1.90$ a day)

Source: World Bank (2016 and 2017 a)

\subsubsection{South Asia}

South Asia (SA) [11] achieved rapid poverty reduction over the past 30 years, even though it is still home to about a third of the world's poor. As shown in Figure 2, although SA had the second highest poverty rate (54.65 percent) in 1981 after EAP, even higher than SSA (49.18 percent), it has since managed to reduce this rate to an estimated 13.5 percent in 2015. The number of people living in extreme 
poverty fell from 538 million in 1981 to about 230 million in 2015 (see Figure 8). However, despite this progress, the region still had around a third of the world's poor population in 2015 .

The severity of poverty in the region, as shown by the PG index, shows that absolute poverty was severe in 1981, estimated at almost 20 percent. By 1999, the PG index had fallen to less than 10 percent and continued to decrease to less than 3 percent in 2013. The same trend was recorded for the SPG index, which decreased from 7.47 in 1981 to less than 1 in 2013 [12].

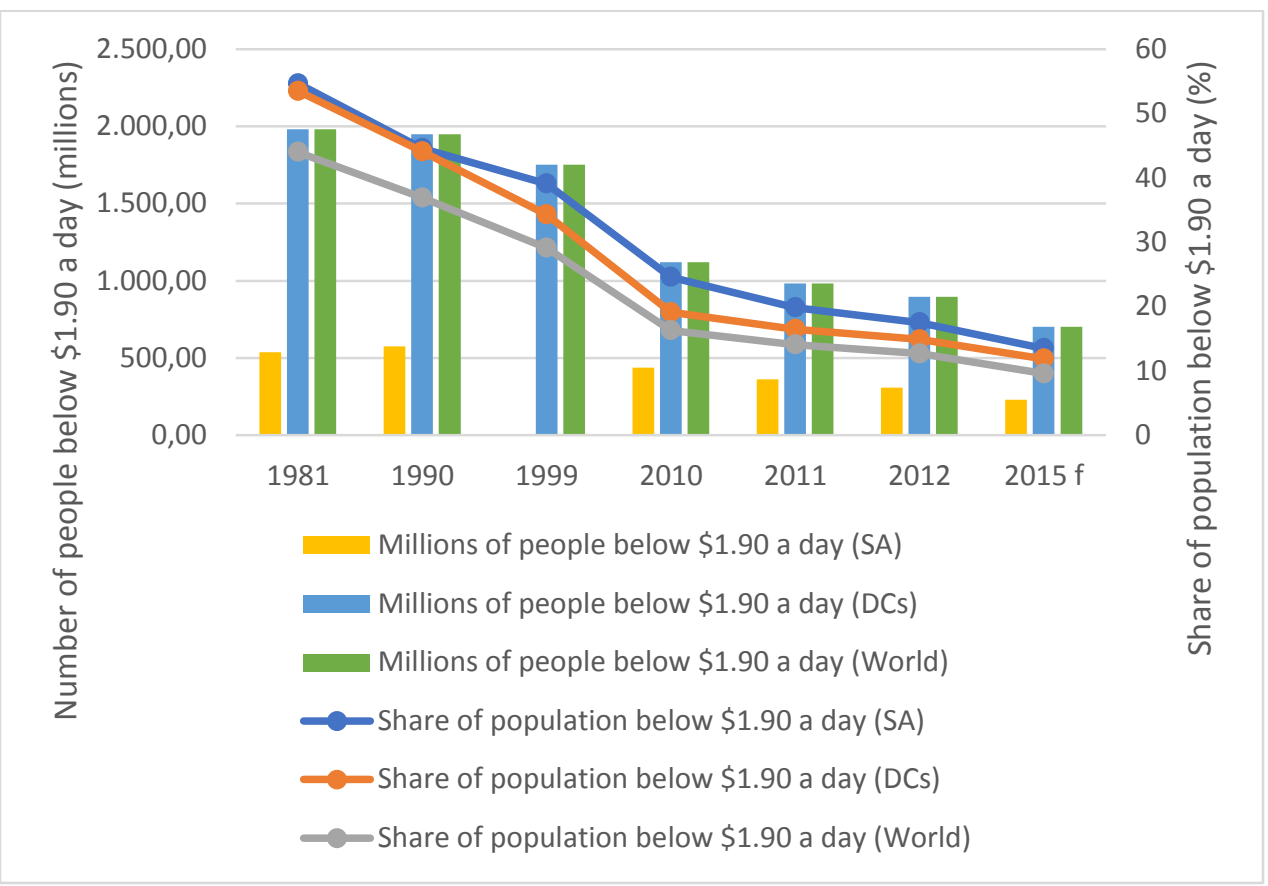

Figure 8. South Asian poverty levels compared to world trends ( $\$ 1.90$ a day)

Source: World Bank (2016 and 2017 a)

\subsubsection{Europe and Central Asia}

Table 2 shows that there was a sharp increase in the poverty measures and the number of people in extreme poverty in Eastern Europe and Central Asia (ECA)[13] in the 1990s. As noted by Ravallion and Chen (1997, p. 10), the ECA countries were undergoing major structural changes during this period. The countries were transitioning from largely planned to market-based economies (Milanovic, 1995). Milanovic (1995, p. 10) further illustrated that the main cause 
of the increase in poverty, especially in Poland, was long-term unemployment and low-paying jobs (for those who were employed).

Overall, the ECA region's headcount poverty rate was below 2 percent in the 1980 s, rising to almost 10 percent in the late 1990s, before coming down to an estimated 1.7 percent in 2015. By 2015, around 4.4 million people were estimated to be living in extreme poverty compared to a peak of 36.8 million in 1990 . The ECA data for the 1980s should, however, be used with caution as the developers of the World Bank PovcalNet database (Ravallion \& Chen, 2010) warned that regional survey data was paucity during this period.

Table 2. Europe and Central Asia poverty levels compared to world trends (\$1.90 a day)

\begin{tabular}{|c|c|c|c|c|c|c|c|}
\hline & 1981 & 1990 & 1999 & 2010 & 2011 & 2012 & 2015 \\
\hline $\begin{array}{l}\text { Share of population below } \\
\$ 1.90 \text { a day (ECA) }\end{array}$ & 1.3 & 1.9 & 7.8 & 2.8 & 2.4 & 2.1 & 1.7 \\
\hline $\begin{array}{l}\text { Share of population below } \\
\$ 1.90 \text { a day (DCs) }\end{array}$ & 53.5 & 44.1 & 34.3 & 19.1 & 16.5 & 14.9 & 11.9 \\
\hline $\begin{array}{l}\text { Share of population below } \\
\$ 1.90 \text { a day (World) }\end{array}$ & 44 & 36.9 & 29.1 & 16.3 & 14.1 & 12.7 & 9.6 \\
\hline $\begin{array}{l}\text { Millions of people below } \\
\$ 1.90 \text { a day (ECA) }\end{array}$ & 5.6 & 8.8 & 36.8 & 13.2 & 11.4 & 10.1 & 4.4 \\
\hline $\begin{array}{l}\text { Millions of people below } \\
\$ 1.90 \text { a day (DCs) }\end{array}$ & 1982.10 & 1948.40 & 1751.50 & 1119.80 & 983.3 & 896.7 & 702.1 \\
\hline $\begin{array}{l}\text { Millions of people below } \\
\$ 1.90 \text { a day (World) }\end{array}$ & 1982.10 & 1948.40 & 1751.50 & 1119.80 & 983.3 & 896.7 & 702.1 \\
\hline
\end{tabular}

Source: World Bank (2016 and 2017a)

\subsubsection{Latin American and the Caribbean}

The Latin America and the Caribbean (LAC)[14] region was home to approximately 600 million people in 2013 and this is estimated to have increased to 638 million by 2016 (World Bank, 2017c). As shown in Figure 9, the incidence of poverty (poverty rates) in LAC has always been lower than the developing world average. The poverty rates fell from 16.15 percent in 1981 to 5.6 percent in 2015 and the number of people living in extreme poverty decreased from 72 million to 30 million.

An analysis of LAC region's poverty trends, in terms of the poverty rate, poverty depth and poverty-severity index for the period 1981 to 2013 show a decrease in poverty over the period [15]. However, the fall in poverty LAC is not as dramatic as in EAP and SA. Perkins, et al. (2013, p. 189) maintain that LAC had limited success at decreasing its poverty levels. 


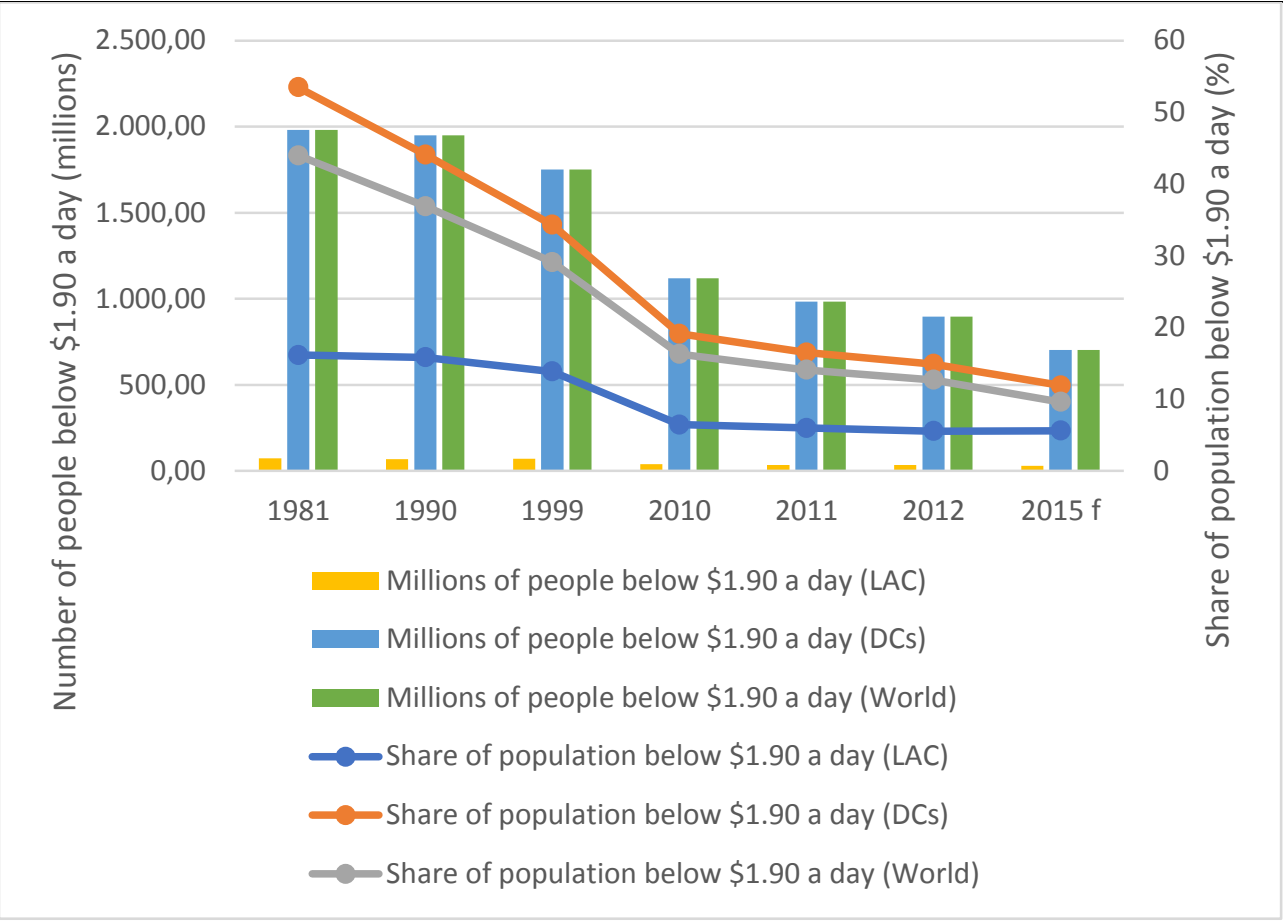

Figure 8. South Asian poverty levels compared to world trends ( $\$ 1.90$ a day)

Source: World Bank (2016 and 2017 a)

\subsection{Progress in meeting the Millennium Development Goals}

The MDGs were promulgated by the United National General Assembly in the year 2000. They were a set of developmental goals and targets agreed by the international community, whose primary focus was halving poverty and improving the welfare of the world's poorest by 2015. There were eight specific and measurable development goals. The first of the seven goals concentrated on eradicating extreme poverty and hunger. Other goals included achieving universal primary education; promoting gender equality and empowering women; reducing child mortality; improving maternal health; combating HIV/AIDS, malaria and other diseases; and ensuring environmental sustainability. The eighth goal focused on the creation of a global partnership for development, with targets for foreign aid, international trade, and debt relief (IMF, 2015).

As noted above, one of the MDGs targets was cutting global poverty by half. That is to reduce the proportion of people living below US\$1 a day[16] from about 30 percent of the developing world's population in 1990 to 15 percent by 2015 
(Besley \& Burgess, 2003, p. 3). To achieve the MDGs goals, rich nations had to make a commitment to increase aid to poor countries by 0.7 percent of their gross national income, a target set since the 1960s.

In 1990, there were around 1.9 billion people living below U\$1.90 a day (constituting 36.9 percent of the world population) and this number is projected to have reduced to 700 million people by 2015 , with an estimated global poverty rate of 9.6percent. Based on these statistics (see also Figure 1and Figure 2), it could be concluded that the world met the MDG target of halving the global poverty rate in 2010, which is five years ahead of schedule (World Bank Group, 2016, p. 1). However, SSA is the only region which has not met its MDG target. Lastly, these recent poverty trends show that poverty is becoming increasingly concentrated in SSA and SA, where its depth and breadth remain a challenge (World Bank, 2016, p. 1).

Despite the progress in meeting the MDG poverty targets, the World Bank (2016, p. 1) argue that though the MDGs were effective in reducing income poverty and in spurring global development progress, they were less successful in improving non-income deprivations, such as access to quality education or to basic health services. The World Bank (2016, p. 2) further asserts that development has advanced more rapidly over the 25 -year MDG era than at any other time in human history, and therefore the lessons learnt could be used to drive the success of the new Sustainable Development Goals (SDGs) by 2030.

\section{Conclusion and Further Directions of Research}

This paper has discussed the dynamics and spread of extreme poverty in the developing world in general and the regional poverty reduction trends, using the assets-based income or monetary indicators of poverty. The dynamics of poverty were explored across countries as well as regions. In order to analyze the dynamics of poverty across different regions, the study grouped countries into five regions, namely: i) sub-Saharan Africa; ii) East Asia and the Pacific (EAP); iii) South Asia; iv) Europe and Central Asia; and v) Latin America and the Caribbean. The main findings of this study revealed that overall, global headcount poverty rates have been decreasing considerably from around 44 percent in 1981 to less than 10 percent in 2015 . For the developing world, the poverty rate decreased from 53 percent to 11.9 percent over the same period. A trend analysis of poverty by regions has revealed that the composition of global poverty across regions has changed significantly. The EAP was the poorest region in the world, with more than 80 percent of its population living on less than US $\$ 1.90$ a day, but they miraculously reduced this rate to 4 percent by 2015 . Poverty rates in SA have also been declining, but not as sharply as in EAP, and the rates remain higher than 
developing country average. SSA remains the poorest region, with more than 35 percent of its citizens living on less than US\$1.90 a day. Half of the world's extremely poor people now live in SSA, and it is the only region which has not met its MDGs target. The world has now moved from the MDGs to the SDGs. However, an important area for further research could be investigating the main reasons for the slow pace in poverty reduction in SSA and whether the new policy thrust in SDGs would be effective.

\section{References}

1. Ali, A. A. G. \& Thorbecke, E., 2000. The state and path of poverty in Sub-Saharan Africa: Some preliminary results. Journal of African Economies, 9 (Supplement 1), pp. $9-40$.

2. Atkinson, A. B. \& Bourguignon, F., 2014. Handbook of income distribution. Amsterdam: Elsevier.

3. Besley, T. \& Burgess, R., 2003. Halving global poverty. Journal of Economic Perspectives, 17(3), pp. 3-22.

4. Bundy, C., 2016. Poverty in South Africa: Past and present. Johannesburg: Jacana Media (Pty) Ltd.

5. Chen, S., Datt, G. \& Ravallion, M., 1994. Is poverty increasing in the developing world? Review of Income and Wealth, 40(4), pp. 359-376.

6. Clunies-Ross, A., Forsyth, D. \& Huq, M., 2009. Development economics. 1st ed. London: McGraw-Hill Higher Education.

7. Deaton, A., 2006. Measuring poverty. In: A. V. Banerjee, R. Benabou \& D. Mookherjee, eds. Understanding poverty. New York: Oxford University Press, pp. 3-15.

8. Deaton, A., 2010. Price indexes, inequality, and the measurement of world poverty. American Economic Review, 100(1), pp. 5-34.

9. IMF, 2015. The IMF and the Millennium Development Goals. [Online]Available at: https://www.imf.org/external/np/exr/facts/mdg.htm [Accessed 15 May 2015].

10. Mahembe, E., 2014. Foreign direct investment inflows and economic growth in SADC countries: a panel data approach, Pretoria: Masters Dissertation, University of South Africa.

11. Milanovic, B., 1995. Poverty, inequality, and social policy in transition economies, Washington DC: World Bank; Policy Research Working Paper Number 1530.

12. Perkins, D. H., Radelet, S., Lindauer, D. L. \& Block, S. A., 2013. Economics of development. 7th ed. New York: W. W. Norton \& Company, Inc.

13. Quibria, M. G., 2002. Growth and poverty: Lessons from the East Asian miracle revisited, Tokyo: Asian Development Bank Institute; ADB Institute Research Paper Number 33.

14. Ravallion, M., 2011. A comparative perspective on poverty reduction in Brazil, China, and India. The World Bank Research Observer, 26(1), pp. 71-104.

15. Ravallion, M., 2016. The economics of poverty: History, measurement, and policy. New York: Oxford University Press.

Studia Universitatis "Vasile Goldis" Arad. Economics Series Vol 28 Issue 2/2018

ISSN: 1584-2339; (online) ISSN: 2285 - 3065 
16. Ravallion, M. \& Chen, S., 1997. What can new survey data tell us about recent changes in distribution and poverty? The World Bank Economic Review, 11(2), pp. 257-382.

17. Ravallion, M. \& Chen, S., 2010. The developing world is poorer than we thought, but no less successful in the fight against poverty. The Quarterly Journal of Economics, 125(4), pp. 1577-1625.

18. Ravallion, M., Datt, G. \& van de Walle, D., 1991. Quantifying absolute poverty in the developing world. Review of Income and Wealth, 37(4), pp. 345-361.

19. Schaffner, J., 2014. Development economics: Theory, empirical research, and policy analysis. Danvers: John Wiley \& Sons, Inc.

20. Tita, A. F. \& Aziakpono, M. J., 2016. Financial development and income inequality in Africa: A panel heterogeneous approach, Cape Town: ERSA Working Paper No. 614.

21. Todaro, M. P. \& Smith, S. C., 2012. Economic development. 11th ed. Boston: AddisonWesley, Pearson Education, Inc.

22. World Bank and International Monetary Fund, 2015. Global monitoring report 2015/2016: Development goals in an era of demographic change. Washington DC: World Bank.

23. World Bank Group, 2016. Global Monitoring Report 2015/2016: Development Goals in an Era of Demographic Change, Washington, DC: World Bank.

24. World Bank, 1990. World Development Report 1990: Poverty. New York: Oxford University Press.

25. World Bank, 2016. Global Monitoring Report 2015/2016: Development Goals in an Era of Demographic Change, Washington, DC: World Bank.

26. World Bank, 2017a. PovcalNet. [Online] Available at: http://iresearch.worldbank.org/PovcalNet/povDuplicateWB.aspx [Accessed 11 November 2017].

27. World Bank, 2017b. The World Bank in Haiti. [Online] Available at: http://www.worldbank.org/en/country/haiti/overview [Accessed 12 August 2017].

28. World Bank, 2017c. World Development Indicators 2017, Washington, DC.: World Bank.

\section{Notes:}

[1] Ravallion et al. (1991), Ravallion et al. (2009), and Deaton (2010).

[2] The headcount index, or the poverty rate measures the proportion of households in a population, with incomes per person below the poverty line.

[3] The Poverty-Gap (PG) index measures the depth of poverty. It averages the proportional income gaps across everyone in the population against the poverty line. According to Schaffner (2014, p. 88), the PG index can be understood as the cost per person for eliminating poverty in the entire country.

[4]The squared poverty-gap (SPG) index is sensitive to both global prevalence and the average depth of poverty, as well as the occurrence of deep poverty among the poor. Because of this wider reach, the index is also referred to as the poverty-severity index.

[5] The top ten poorest countries of the world in terms of 2013 headcount poverty levels are Central African Republic, Madagascar, Democratic Republic of Congo, Burundi, South 
Sudan, Malawi, Guinea-Bissau, Zambia, Rwanda and Mozambique, starting with the poorest.

[6] According to Ali and Thorbecke (2000, p. 10) a PIC "is generated by plotting the proportion of population (p) - on the vertical axis-consuming less than a given level $\mathrm{z}$ - on the horizontal axis; each point on the PIC gives the head-count index of poverty. Poverty deficit curves $\mathrm{O}(\mathrm{z})$ and poverty sensitivity curves $5(\mathrm{z})$ can be obtained from the PICs. Using these curves and assuming that the poverty line $\mathrm{z}$ is unknown, comparing poverty between two dates is conducted by dates if the PlC for the latter date always lies above that for the former date up to a maximum poverty line. If the PlC for the two dates cross, then the ranking is ambiguous. The poverty deficit $\mathrm{O}(\mathrm{z})$ and the poverty sensitivity $5(\mathrm{z})$ curves provide second- and third-order dominance respectively. Dominance tests are nested in the sense that first-order dominance implies second-order dominance, which in turn implies third-order dominance".

[7] The Ravallion and Chen (1997) study included a sub-sample of 19 SSA countries (with 28 surveys) representing 65.9 percent of the region's population in 1993.

[8] Not shown in any of the figures and tables herein.

[9] Not shown in any of the figures and tables herein.

[10] The sample of countries in the EAP region is 19, which include: Solomon Islands, Papua New Guinea, Timor-Leste, Federated States of Micronesia, Lao People's Democratic Republic, Vanuatu, Kiribati, Philippines, Indonesia, Fiji, China, Vietnam, Tuvalu, Cambodia, Samoa, Tonga, Mongolia, Malaysia, and Thailand.

[11] The sample of countries in South Asia is 7, including: India, Bangladesh, Nepal, Pakistan, Maldives, Sri Lanka and Bhutan.

[12] Not shown in any of the figures and tables herein.

[13] Our ECA sample consist of 30 countries, namely: Albania, Armenia, Azerbaijan, Belarus, Bosnia and Herzegovina, Bulgaria, Croatia, Czech Republic, Estonia, Georgia, Hungary, Kazakhstan, Kosovo, Kyrgyz Republic, Latvia, Lithuania, Macedonia (former Republic of Yugoslav), Moldova, Montenegro, Poland, Romania, Russian Federation, Serbia, Slovak Republic, Slovenia, Tajikistan, Turkey, Turkmenistan, Ukraine, Uzbekistan. [14] Though there are more than 30 countries in this region, our sample size, based on the availability of poverty data is 25 countries. These countries include: Argentina, Belize, Bolivia, Brazil, Chile, Colombia, Costa Rica, Dominican Republic, Ecuador, El Salvador, Guatemala, Guyana, Haiti, Honduras, Jamaica, Mexico, Nicaragua, Panama, Paraguay, Peru, St. Lucia, Suriname, Trinidad and Tobago, Uruguay, Venezuela and Republica Bolivariana de.

[15] Not shown in any of the figures and tables herein.

[16] Which is now estimated at US\$1.90 a day. 